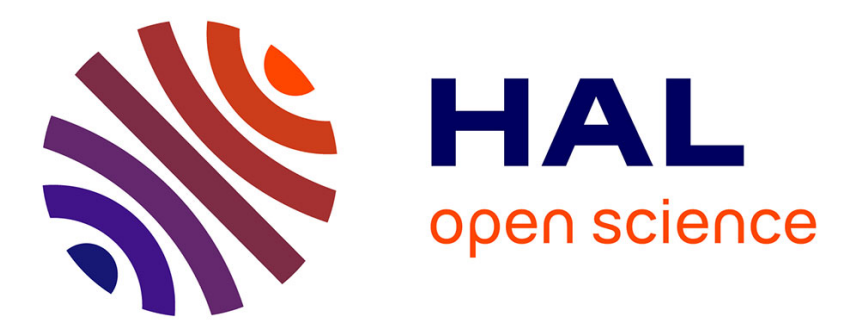

\title{
Comparison of $\beta$-dimethylsulfoniopropionate (DMSP) levels in two mediterranean ecosystems with different trophic levels
}

\author{
Natacha Jean, Gérard Bogé, Jean-Louis Jamet, Dominique Jamet
}

\section{To cite this version:}

Natacha Jean, Gérard Bogé, Jean-Louis Jamet, Dominique Jamet. Comparison of $\beta$ dimethylsulfoniopropionate (DMSP) levels in two mediterranean ecosystems with different trophic levels. Marine Chemistry, 2006, 101 (3-4), pp.190 - 202. 10.1016/j.marchem.2006.03.001 . hal01893686

\section{HAL Id: hal-01893686 \\ https://hal.science/hal-01893686}

Submitted on 1 Jun 2021

HAL is a multi-disciplinary open access archive for the deposit and dissemination of scientific research documents, whether they are published or not. The documents may come from teaching and research institutions in France or abroad, or from public or private research centers.
L'archive ouverte pluridisciplinaire HAL, est destinée au dépôt et à la diffusion de documents scientifiques de niveau recherche, publiés ou non, émanant des établissements d'enseignement et de recherche français ou étrangers, des laboratoires publics ou privés. 


\title{
Comparison of $\beta$-dimethylsulfoniopropionate (DMSP) levels in two mediterranean ecosystems with different trophic levels
}

\author{
Natacha Jean ${ }^{\mathrm{a}, *}$, Gérard Boge ${ }^{\mathrm{b}}$, Jean-Louis Jamet ${ }^{\mathrm{b}}$, Dominique Jamet ${ }^{\mathrm{b}}$

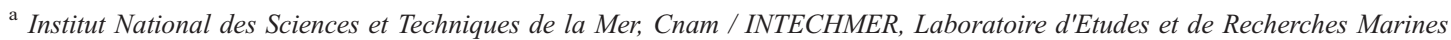 \\ (L.E.R.M.A., EA 3202), Digue de Collignon, BP 324, 50103 Cherbourg cedex, France \\ ${ }^{\mathrm{b}}$ Université du Sud Toulon-Var, Equipe de Biologie des Milieux Aquatiques (E.B.M.A.), Laboratoire des Processus de Transfert et des Echanges en \\ Environnement, (P.R.O.T.E.E., EA 3819), B.P. 20132. 83957 La Garde cedex, France
}

\begin{abstract}
$\beta$-dimethylsulfoniopropionate (DMSP) and dimethylsulfide (DMS) concentrations were recorded from September 1999 to September 2000 in two geographically close ecosystems, differently affected by eutrophication: the Little Bay of Toulon and the Niel Bay (N.W. Mediterranean Sea, France). Little Bay had higher nutrient levels $\left(\left[\mathrm{NO}_{3}^{-}\right]_{\max .}=30.3 \mu \mathrm{M} ;\left[\mathrm{PO}_{4}^{3-}\right]_{\max .}=0.46 \mu \mathrm{M}\right)$ and higher chlorophyll $a$ concentrations $\left([\mathrm{chl} a]_{\text {mean }}=2.4 \mu \mathrm{g} / \mathrm{L}\right)$ compared to Niel Bay $\left(\left[\mathrm{NO}_{3}^{-}\right]_{\max .}=19.7 \mu \mathrm{M} ;\left[\mathrm{PO}_{4}^{3-}\right]_{\max .}=0.17 \mu \mathrm{M}\right.$; $\left.[\mathrm{chl} a]_{\text {mean }}=0.4 \mu \mathrm{g} / \mathrm{L}\right)$. In the two sites, we measured dissolved $\left(\operatorname{DMSP}_{\mathrm{d}}<0.2 \mu \mathrm{m}\right)$ and particulate DMSP $\left(\operatorname{DMSP}_{\mathrm{p}}>0.2 \mu \mathrm{m}\right)$ concentrations. The DMSP ${ }_{\mathrm{p}}$ was particularly analysed in the $0.2-5,5-90$ and $>90 \mu \mathrm{m}$ fractions. In the eutrophicated Little Bay, DMSP $_{d}$ concentrations showed a clear seasonality with high values from January to March (124-148 nM). The temporal profile of the DMSP $_{p}$ concentrations was similar, peaking in February-March $(38-59 \mathrm{nM})$. In the less eutrophic Niel Bay, DMSP $_{p}$ concentrations were much lower (6-9 nM in March-April), whereas DMSP ${ }_{d}$ concentrations were relatively high (110-92 nM in February-March). DMS concentrations were elevated from the end of the winter to the spring in Little Bay, ranging from $3 \mathrm{nM}$ in October to $134 \mathrm{nM}$ in March. In the less eutrophic Niel Bay, lower DMS levels were observed, generally not exceeding $20 \mathrm{nM}$. Each particulate fraction $(0.2-5 ; 5-90 ;>90 \mu \mathrm{m})$ contained less DMSP in Niel Bay than in Little Bay. At both sites, the 5-90 $\mu \mathrm{m}$ fraction made up most of the $\mathrm{DMSP}_{\mathrm{p}}$. This 5-90 $\mu \mathrm{m}$ fraction consisted of microphytoplankton, principally Dinophyceae and Bacillariophyceae. The 5-90 $\mu \mathrm{m}$ biomass calculated from cell biovolumes, was more abundant in Little Bay where the bloom at

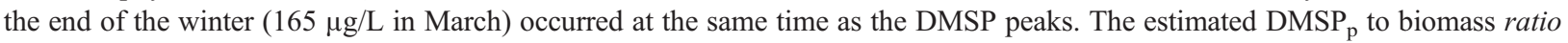
for the 5-90 $\mu \mathrm{m}$ fraction was always higher in Little Bay than in Niel Bay. This suggests that the high DMSP levels recorded in Little Bay were not only due to a large Dinophyceae presence in this ecosystem. Indeed, the peak of DMSP $\mathrm{p}_{\mathrm{p}}$ to biomass ratio obtained from cell biovolumes $(0.23 \mathrm{nmol} / \mu \mathrm{g}$ in March) was consistent with the proliferation of Alexandrium minutum. This Dinophyceae species may account for between 50\% (2894 cells/L) and 63\% (4914 cells/L) of the total phytoplankton abundance in the Little Bay of Toulon.
\end{abstract}

Keywords: DMSP; DMS; Mediterranean Sea; Alexandrium minutum; Eutrophication

\footnotetext{
* Corresponding author. Tel.: +33233887336; fax: +33233887339.

E-mail address: natacha.jean@cnam.fr (N. Jean).
} 


\section{Materials and methods}

\section{Introduction}

Dimethylsulfide (DMS) is the main source of biogenic volatile sulfur compounds found in the atmosphere (Stefels, 1997). According to the CLAW hypothesis, DMS may influence the climate by regulating the increased greenhouse effect (Charlson et al., 1987). DMS is derived from enzymatic cleavage of $\beta$-dimethylsulfoniopropionate (DMSP) (Challenger, 1951), which is involved in the osmoregulation and the cryoprotection of marine algae (Andreae, 1990; Kiene and Service, 1991; Kirst et al., 1991). After demethylation or demethiolation, bacteria can use DMSP as a source of reduced sulfur (Kiene et al., 1999; Kiene and Linn, 2000). More recent studies have shown that DMSP and its degradation products have antioxidant properties for marine phytoplankton (Steinke et al., 2002; Sunda et al., 2002; Van Rijssel and Buma, 2002).

There have been very few investigations into the influence of eutrophication on the DMS(P) cycle, especially in shallow coastal systems. According to Kwint et al. (1993), experiments reflecting different trophic levels cannot be easily carried out in the laboratory. As a result, these experiments are difficult to transpose to the marine environment. The present study is a comparison of the DMSP concentrations measured in two coastal ecosystems of the N.W. Mediterranean: the eutrophic Little Bay of Toulon and the less eutrophic Niel Bay. We aim to describe the impact of eutrophication on the evolution of DMSP concentrations in the phytoplankton communities at the two different sites during a full year (September 1999 to September 2000).

\subsection{Study sites}

The study was carried out in two Mediterranean ecosystems: the Little Bay of Toulon $\left(\mathrm{S}_{1}\right.$; depth= $13 \mathrm{~m})$ and the Niel Bay $\left(\mathrm{S}_{2}\right.$; depth=4 m) (Fig. 1). Toulon Bay (Lat. $43^{\circ} 05^{\prime} \mathrm{N}$ and Long. $6^{\circ} 00^{\prime} \mathrm{E}$ ) is located on the French N.W. Mediterranean coast. Its seaport handles a large amount of military and commercial traffic. Toulon Bay is composed of two areas separated by a breakwater: the western basin, also called Little Bay is semi-enclosed, whereas the eastern basin, also called Large Bay, is open to the sea. According to Ifremer, Little Bay is contaminated by chemical pollutants, such as organic compounds (PCB, anti-fouling paints), heavy metals $(\mathrm{Hg}, \mathrm{Zn}, \mathrm{Pb}$ and $\mathrm{Cu}$ ) and occasionally by toxic plankton species, such as Alexandrium minutum and Dinophysis spp. (Belin et al., 1995; Ifremer, 1997).

Niel Bay is widely open to the sea and is located $15 \mathrm{~km}$ from the city of Toulon, outside of Toulon Bay (Fig. 1). Niel, the port on the Giens peninsula, handles only small fishing and modest tourist traffic in the summer. Porquerolles Island, just in front of Niel Bay, represents a natural protected area. Niel Bay is characterized by a marine plant habitat of Posidonia oceanica. This species is protected at the international level and is still present in vast areas of Niel Bay. P. oceanica brings sufficient dioxygen concentrations to allow development of seventy fish species. While $P$.

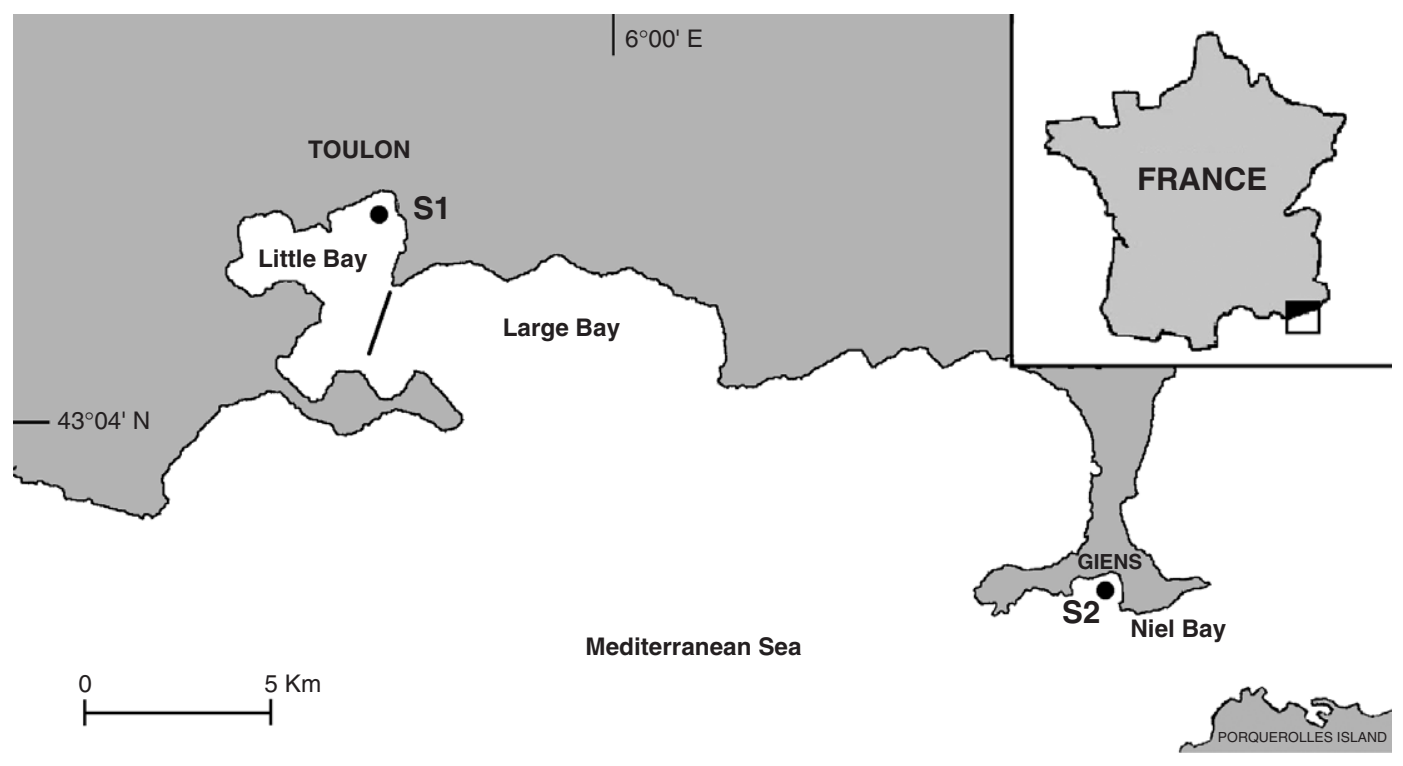

Fig. 1. Location of the sampling stations in Little Bay $\left(\mathrm{S}_{1}\right)$ and Niel Bay $\left(\mathrm{S}_{2}\right)$. 
oceanica knows a strong regression in many mediterranean zones, its presence in Niel Bay shows evidence of a healthy ecosystem (Paillard et al., 1993).

\subsection{Field sampling}

Samples were collected monthly from September 1999 to September 2000, between 9:00 a.m. and 11:00 a.m., in the Little Bay of Toulon $\left(\mathrm{S}_{1}\right)$ and in Niel Bay $\left(\mathrm{S}_{2}\right)$. Water samples were systematically taken from a depth of $2 \mathrm{~m}$, using a Niskin $10 \mathrm{~L}$ sampling bottle. DMSP $_{\mathrm{p}}$ (particulate DSMP) analysis was performed on a $4 \mathrm{~L}$ aliquot in $\mathrm{S}_{1}$ and on a $8 \mathrm{~L}$ aliquot in $\mathrm{S}_{2}$. At the two sites, $\mathrm{DMSP}_{\mathrm{d}}$ (dissolved DSMP) concentrations were determined from a $250 \mathrm{~mL}$ subsample of filtered seawater. In $\mathrm{S}_{1}$, several ten-litre samples were taken to study the phytoplankton community, and to measure chlorophyll $a$ and protein concentrations, with $20 \mathrm{~L}$ samples being taken in $\mathrm{S}_{2}$. Samples for DMS determination were carefully collected to avoid headspace and degassing in the sampling bottle. DMS analysis was performed from a $250 \mathrm{~mL}$ subsample of unfiltered seawater.

\section{3. $D M S P_{p}, D M S P_{d}$ and $D M S$ analysis}

$\operatorname{DMSP}_{\mathrm{p}}$ was fractionated into size classes by successively filtering seawater samples through polyamide membranes (Nytrel-TI, UGB) with 90, 5 and $0.2 \mu \mathrm{m}$ pore size. Gravity filtration was used for the $90 \mu \mathrm{m}$ pore membranes, whereas gentle pressure was used to separate the 5-90 $\mu \mathrm{m}$ fraction and the $0.2-$ $5 \mu \mathrm{m}$ fraction. Each filter was put into $250 \mathrm{~mL}$ of cold distilled water, and then, resuspension and extraction of DMSP from the particulate was carried out using sonication. $\mathrm{DMSP}_{\mathrm{d}}$ was isolated from the $\mathrm{DMSP}_{\mathrm{p}}$ by filtering $250 \mathrm{~mL}$ seawater through a membrane with $0.2 \mu \mathrm{m}$ pores. According to Bates et al. (1994), the distribution of DMSP between particulate and dissolved fractions may depend on filtering pressure. Cell lysis which occurs during filtration, may induce a decrease in $\mathrm{DMSP}_{\mathrm{p}}$ and an increase in $\mathrm{DMSP}_{\mathrm{d}}$. In this study, we estimated the losses due to filtration by comparison of the $\mathrm{DMSP}_{\mathrm{p}}$ concentrations coming from subsamples filtered through $0.2 \mu \mathrm{m}$ pore size, respectively using gravity and gentle pressure. As a result, the losses of $\mathrm{DMSP}_{\mathrm{p}}$ due to filtration were estimated at $37.3 \% \pm 7.9 \%(n=4)$.

The seawater DMSP determination requests the

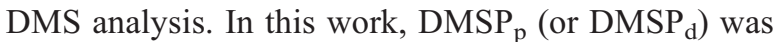
therefore converted into DMS using the cold alkali treatment method (Dacey and Blough, 1987; Turner et al., 1988). $\mathrm{NaOH}(10 \mathrm{M})$ was added until a $\mathrm{pH}$ of approximately 13 was attained (White, 1982; Stefels and Van Boekel, 1993). The alkaline solution was transferred to a silanized glass bottle with septum and no headspace. DMSP was fully transformed into DMS after $24 \mathrm{~h}$ in the dark at $2{ }^{\circ} \mathrm{C}$. DMS was analysed according to a modified method based on a cryotrapping gas chromatographic technique (Simo et al., 1993; Simo, 1998). The gas chromatograph (DELSI 330) was equipped with a flame photometric detector (FPD) and a 1/8" PTFE column filled with Chromosil 330 (Supelco). Subsamples $(5 \mathrm{~mL})$ were taken from the alkaline solution with a polyethylene needle and the DMS was purged from the solution with $99.99 \%$ helium at a flow rate of $100 \mathrm{~mL} / \mathrm{min}$ and trapped onto Tenax T.A. packed at $-40{ }^{\circ} \mathrm{C}$, and dried using magnesium perchlorate (Despiau et al., 2002). The Tenax was heated to $180^{\circ} \mathrm{C}$ and DMS was transferred onto the column. The flame photometric detector was supplied with a flow of air $\left(F_{\mathrm{a}}=150 \mathrm{~mL} / \mathrm{min}\right)$ and hydrogen $\left(F_{\text {red }}=75 \mathrm{~mL} / \mathrm{min} ; F_{\text {oxy }}=7 \mathrm{~mL} / \mathrm{min}\right)$. Calibration was made with a DMS solution, using linear interpolation: $\ln$ (Peak area)- $\ln$ (DMS mass). The minimal quantity of detected DMS was equivalent to a peak amplitude two times higher than the baseline noise. The corresponding limit of detection was determined by analysing decreased DMS quantities. This limit of detection reached $2 \mathrm{ng}$ DMS. The average precision of DMS concentrations, obtained by carrying out different injections $(n=9)$ of fixed DMS concentrations, was $13 \%$. The DMSP measurements were carried out in triplicates and average DMSP values are presented with their standard deviations.

\subsection{Biotic parameters}

\subsubsection{Phytoplankton counts and biomass}

Samples of phytoplankton were preserved in an alkaline Lugol solution. Phytoplankton were identified to species level if possible and cells were counted under an inverted microscope $(\times 400)$ according to Utermohl (1958) and the Lund Cell technique (Lund et al., 1958). Phytoplankton cells were counted in at least 40 fields, with at least 400 cells over all fields. At least 100 cells of the most abundant species were counted. Counts were then extrapolated to provide concentrations per litre (cells/L). The biomasses were then estimated according to Lohman's (1908) calculation technique.

\subsubsection{Chlorophyll a}

Seawater samples were filtered using glass fibre filters (Whatman GF/C). Cells collected on the filters 
were extracted with $90 \%$ acetone to yield chlorophyll a. Chlorophyll a determination was carried out according to the visible spectrophotometric method described by Lorenzen (1967).

\subsubsection{Protein analysis}

Seawater samples were filtered through polyamide membranes (Nytrel-TI, UGB) to collect the 5-90 $\mu \mathrm{m}$ particulate fraction. Proteins collected on the filter were stored at $-80{ }^{\circ} \mathrm{C}$ in $15 \mathrm{~mL}$ polyethylene bottles until analysis. After resuspension in distilled water, proteins were analysed with Folin phenol reagent (Lowry et al., 1951). Bovine serum albumin (BSA) was used as a standard. Each protein measurement was carried out in triplicate.

\subsection{Abiotic parameters}

Meteorological data were obtained from Météo-France. Seawater temperature and salinity were measured $( \pm 0.1 \%$ o and $\pm 0.1{ }^{\circ} \mathrm{C}$ ) at a depth of $2 \mathrm{~m}$ with a WTW thermosalinometer (LF 197 model). Orthophosphate concentrations $\left(\mathrm{P}-\mathrm{PO}_{4}\right)$ were determined according to the method of Murphy and Riley (1962). The technique of Wood et al. (1967) modified by Le Poupon (1994) was used to estimate the nitrate levels $\left(\mathrm{N}-\mathrm{NO}_{3}\right)$ in seawater.

\section{Results}

\subsection{Abiotic parameters}

A large drop in salinity from $37.3 \%$ to $29.0 \%$ o occurred in Little Bay $\left(\mathrm{S}_{1}\right)$, between September and October 1999 as a result of heavy autumnal rains
(288 $\mathrm{mm}$ in October) (Fig. 2A). The salinity then gradually increased and stabilized at around $38 \%$, from February. In Niel Bay $\left(\mathrm{S}_{2}\right)$, the decrease of salinity was less severe, with values reaching 35.9\% in September and 35.2\%o in October 1999 (Fig. 2B).

In Little Bay, the annual mean nutrient concentration was $8.8 \mu \mathrm{M}$ for nitrate and $0.13 \mu \mathrm{M}$ for phosphate (Fig. 3A). In Niel Bay, these concentrations were lower and reached $5.5 \mu \mathrm{M}$ for nitrate and $0.10 \mu \mathrm{M}$ for phosphate (Fig. 3B). After the autumnal rains, the maximum nutrient concentrations were less important in Niel Bay $\left(\left[\mathrm{NO}_{3}\right]_{\max }=19.7 \mu \mathrm{M}\right.$ in December; $\left[\mathrm{PO}_{4}\right]_{\max }=0.17 \mu \mathrm{M}$ in November) than in Little Bay $\left(\left[\mathrm{NO}_{3}\right]_{\max }=30.3 \mu \mathrm{M}\right.$ in October; $\left[\mathrm{PO}_{4}\right]_{\max }=0.35 \mu \mathrm{M}$ in October).

\subsection{Chlorophyll a}

There were higher levels of chlorophyll $a$ in Little Bay than in Niel Bay, throughout the year (Wilcoxon rank sum test: the $p$-value is the probability when the null hypothesis $\mathrm{H}_{0}$ is true, it is generally accepted that the two populations are significantly different when $p<0.05$, here, the Statview ${ }^{\circledR}$ software gives $p=0.001$ ) (Fig. 4A). The annual mean value of chlorophyll $a$ was of $2.4 \mu \mathrm{g} / \mathrm{L}$ in Little Bay with peaks reaching $9.0 \mu \mathrm{g} / \mathrm{L}$ (in September 1999), whereas the annual mean value in Niel Bay was only $0.4 \mu \mathrm{g} / \mathrm{L}$.

\subsection{Phytoplankton communities}

The algal communities in the two bays were principally composed of microphytoplankton: Bacillariophyceae and Dinophyceae. The total microphytoplankton biomasses, calculated from cell biovolumes, were
(A)

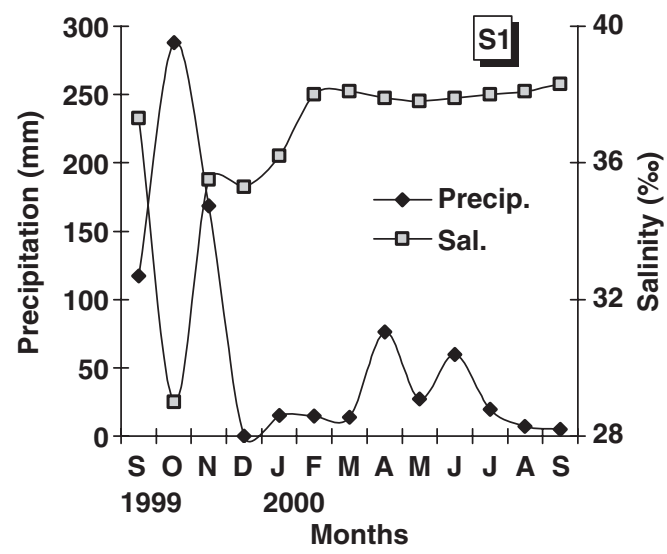

(B)

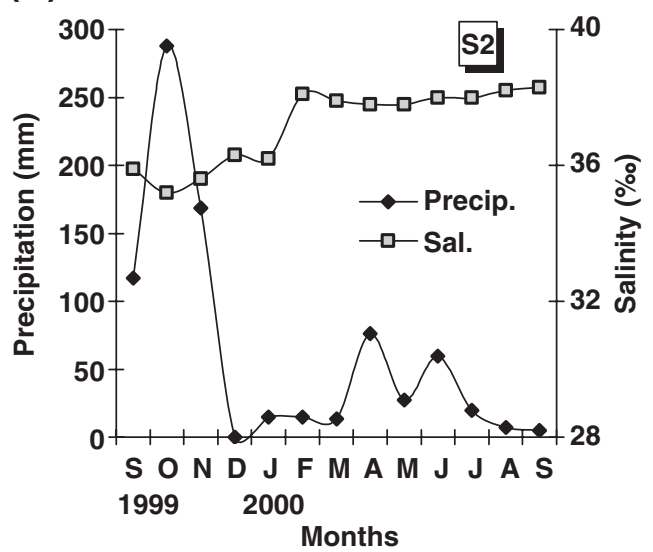

Fig. 2. Temporal variations in precipitation and salinity in Little Bay $\left(\mathrm{S}_{1}\right)$ (Fig. A) and Niel Bay $\left(\mathrm{S}_{2}\right)($ Fig. B). 
(A)

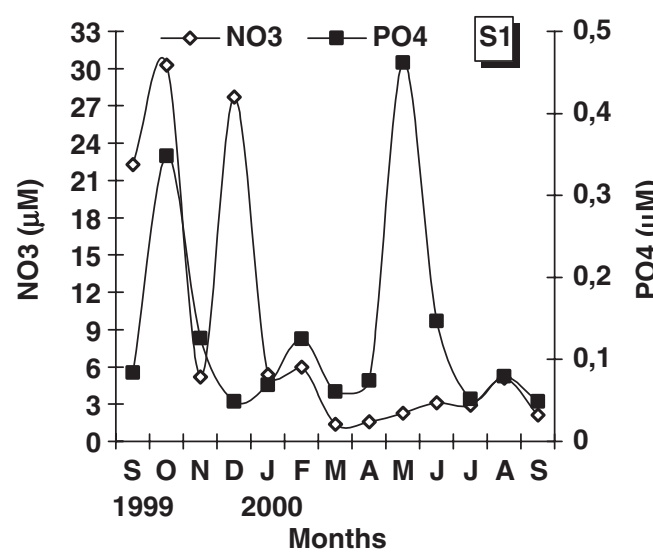

(B)

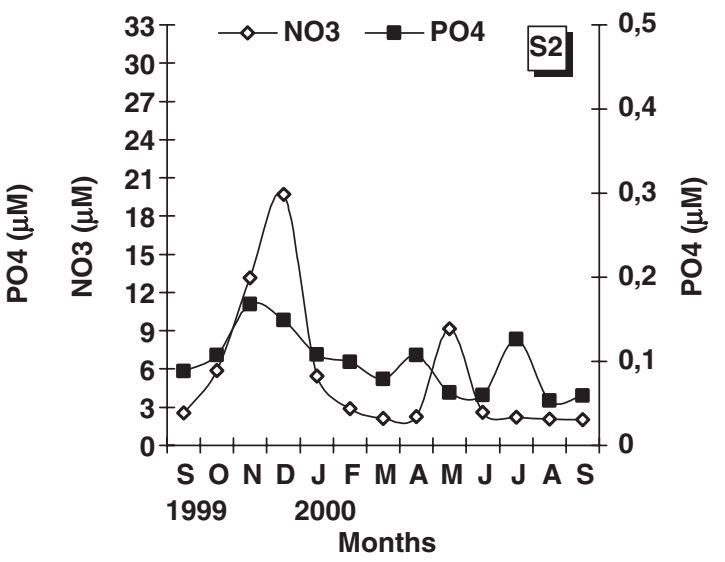

Fig. 3. Temporal variations in nitrate and orthophosphate concentrations in Little Bay $\left(\mathrm{S}_{1}\right)\left(\mathrm{Fig}\right.$. A) and Niel Bay $\left(\mathrm{S}_{2}\right)\left(\mathrm{Fig}_{1}\right.$. B).

always much higher in Little Bay than in Niel Bay (Wilcoxon rank sum test: $p=0.001$ ) (Fig. 4B). In Little Bay, the microphytoplankton biomass showed a sharp seasonal evolution, with a main bloom at the end of the winter $(165 \mu \mathrm{g} / \mathrm{L}$ in March), whereas in Niel Bay, the maximum algal development occurred in spring $(33 \mu \mathrm{g} / \mathrm{L}$ in May).

In Little Bay, Dinophyceae were responsible for most of the microphytoplankton biomass, contributing between $42 \%$ and $100 \%$ (respectively in December and MarchJune) of the biomass (Fig. 5A). By contrast, there was very little Bacillariophyceae, except in December (58\%) and in August (30\%). In Niel Bay, Dinophyceae were also the most predominant, however, their relative biomasses were less than in Little Bay (Wilcoxon rank sum test: $p=0.002$ ) (Fig. 5B). Bacillariophyceae biomass was much higher in Niel Bay than in Little Bay $(p=0.033)$. For example, in December, Bacillariophyceae made up $80 \%$ of the phytoplankton biomass in Niel Bay.

\section{4. $\mathrm{DMSP}_{p}$ concentrations}

We analysed DMSP concentrations in the particulate material collected on $0.2 \mu \mathrm{m}$ pore filters (Fig. 6A). In Little Bay, the $\mathrm{DMSP}_{\mathrm{p}}$ curve followed the same trend as for $\mathrm{DMSP}_{\mathrm{d}}$ concentrations (Correlation with Spearman test: $r=0.687 ; p=0.017)$. The $\mathrm{DMSP}_{\mathrm{p}}$ concentrations were high and showed a marked seasonality. Throughout winter, a gradual increase in $\mathrm{DMSP}_{\mathrm{p}}$ was observed, with a maximum through February and March (38-59 nM).
(A)

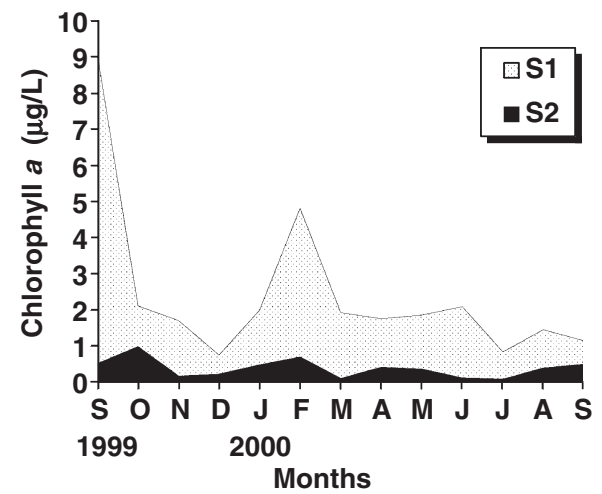

(B)

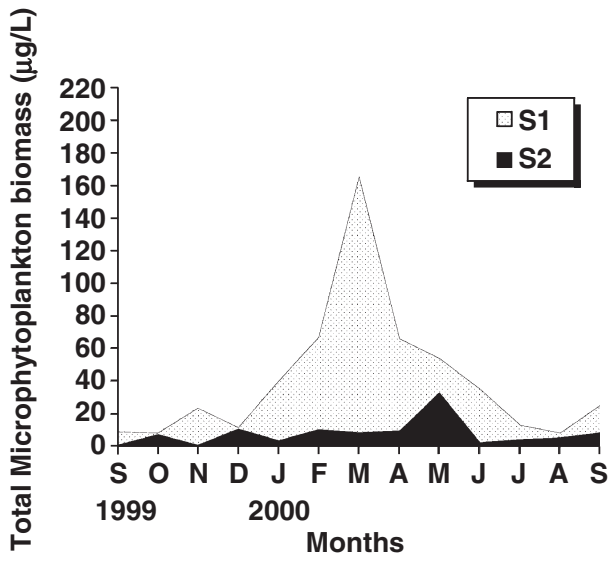

Fig. 4. Temporal variation in the chlorophyll $a$ concentrations (Fig. A) and in the total microphytoplankton biomass (Fig. B) in Little Bay ( $\left.\mathrm{S}_{1}\right)$ and Niel Bay $\left(\mathrm{S}_{2}\right)$ 
(A)

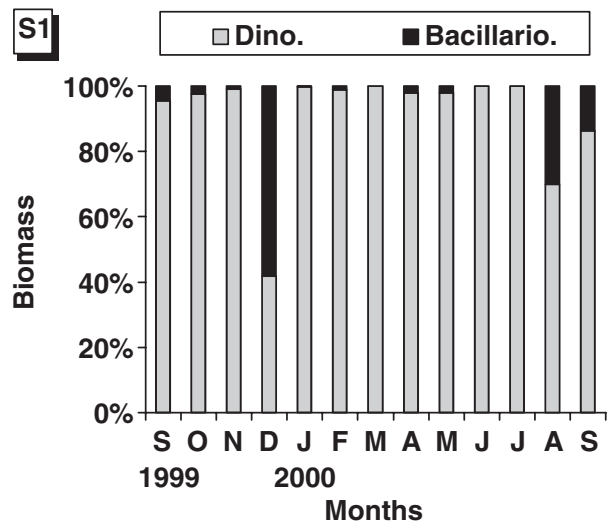

(B)

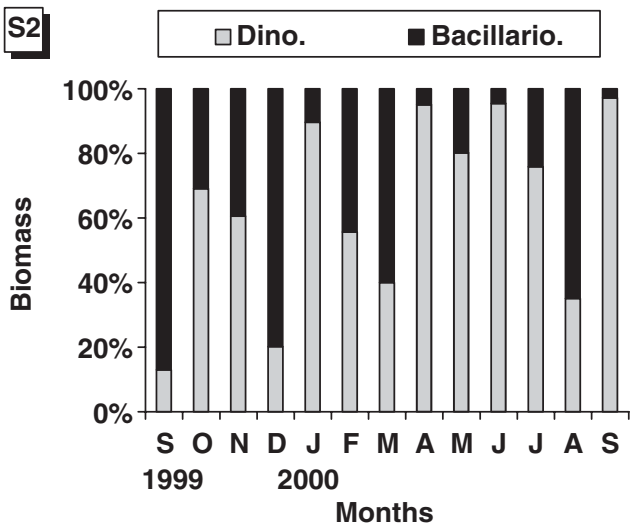

Fig. 5. Relative contributions of Dinophyceae and Bacillariophyceae to the total microphytoplankton biomass in Little Bay ( $\left.\mathrm{S}_{1}\right)$ (Fig. A) and Niel Bay $\left(\mathrm{S}_{2}\right)$ (Fig. B).

In spring and summer, the concentrations decreased and reached $21 \mathrm{nM}$ in September 2000.

In Niel Bay, the DMSP $_{\mathrm{p}}$ concentrations were generally much lower than in Toulon Bay (Wilcoxon rank sum test: $p=0.002$ ). Although temporal evolutions in the two sites were correlated (Correlation Spearman test: $r=0.610 ; p=0.035$ ), variations in $\mathrm{DMSP}_{\mathrm{p}}$ were less marked in Niel Bay. The main event was a relative peak of concentrations in March-April (6-9 nM), one month later than in Little Bay.

\subsection{DMSP $P_{d}$ concentrations}

We found high concentrations of dissolved DMSP in seawater filtered through $0.2 \mu \mathrm{m}$ pore membranes (Fig. $6 \mathrm{~B})$. Besides, these concentrations were comparable in both Little Bay and Niel Bay.

In Little Bay, $\mathrm{DMSP}_{\mathrm{d}}$ concentrations peaked in winter, with the maxima stretching from January to March (124-148 nM). An additional peak of DMSP was also recorded in November $(123 \mathrm{nM})$. A similar pattern was observed for the $\mathrm{DMSP}_{\mathrm{d}}$ in Niel Bay, with the maximum through February and March (110$92 \mathrm{nM})$, and a peak in November $(83 \mathrm{nM})$.

\subsection{DMS concentrations}

Most often, DMS concentrations were high in Little Bay, varying between $3 \mathrm{nM}$ in October and $134 \mathrm{nM}$ in March (Fig. 6C). Temporal evolution of the DMS concentrations was similar to the temporal evolution of the DMSP concentrations in the 5-90 $\mu \mathrm{m}$ fraction (Correlation Spearman test: $r=0.560 ; p=0.052$ ). DMS concentrations gradually increased at the end of the winter and stayed very elevated (higher than $100 \mathrm{nM}$ ) during the whole spring. A different pattern was observed in Niel Bay, where concentrations showed a non-seasonal variability. Except in April $(74 \mathrm{nM})$ and in August (65 nM), DMS levels did not exceed $20 \mathrm{nM}$ and were significantly lower than in Little Bay (Wilcoxon rank sum test: $p=0.023$ ). In both Little Bay and Niel Bay, DMSP concentrations were often higher than DMS concentrations, except in April-May in $\mathrm{S}_{1}$ and in July-August in $\mathrm{S}_{2}$.

\section{7. $\mathrm{DMSP}_{d} / \mathrm{DMSP} P_{p}$ ratio}

At the two sites, the $\mathrm{DMSP}_{\mathrm{d}}$ concentrations were always higher than the $\mathrm{DMSP}_{\mathrm{p}}$ concentrations (Wilcoxon rank sum test: $p=0.011$ in Little Bay; $p=0.019$ in Niel Bay). Therefore, the $\mathrm{DMSP}_{\mathrm{d}}$ to $\mathrm{DMSP}_{\mathrm{p}}$ ratio was always high, especially in Niel Bay, where it reached an exceptional value of 99.0 in November after the autumnal rains $(288 \mathrm{~mm}$ in October; $167 \mathrm{~mm}$ in November) (Fig. 7). In stable meteorological conditions, this ratio decreased and stabilised to between 6.9 (January) and 0.2 (September 2000).

\subsection{Distribution of $\mathrm{DMSP}_{p}$ between size classes}

We measured the DMSP concentrations in the $0.2-5$, 5-90 and $>90 \mu \mathrm{m}$ fractions (Fig. 8) and estimated the relative contributions of these fractions to the total DMSP $_{\mathrm{p}}$ (in \%) (Fig. 9).

In Little Bay, the temporal profiles of the DMSP concentrations were similar for all the three fractions (Correlation Spearman test: $r=0.626$ for $>90$ and 5$90 \mu \mathrm{m} ; r=0.779$ for $>90$ and $0.2-5 \mu \mathrm{m}$ ). For all fractions, 
(A)

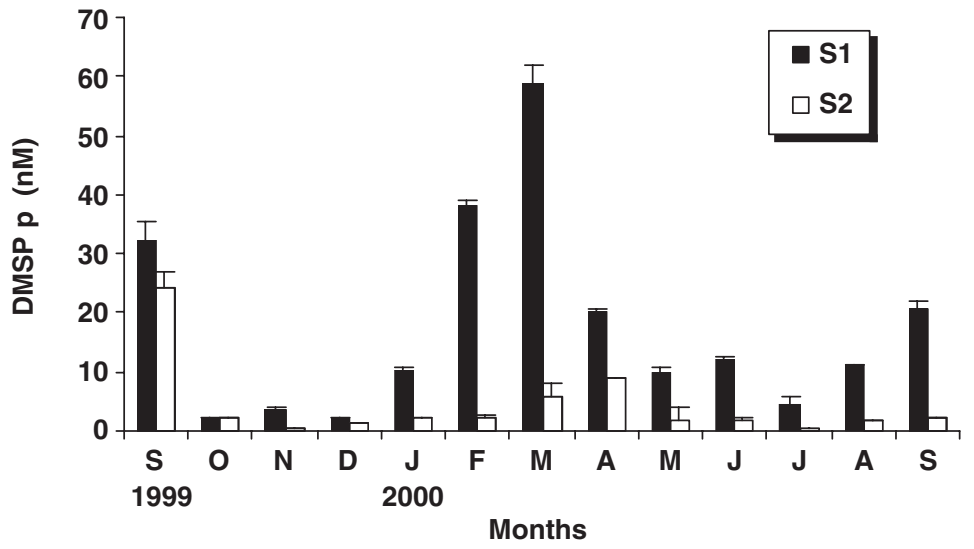

(B)

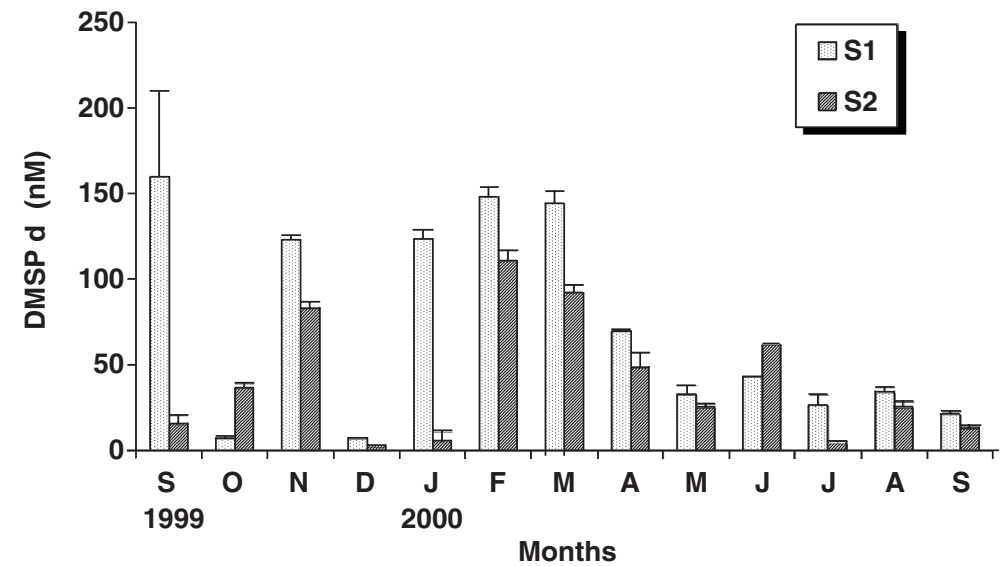

(C)

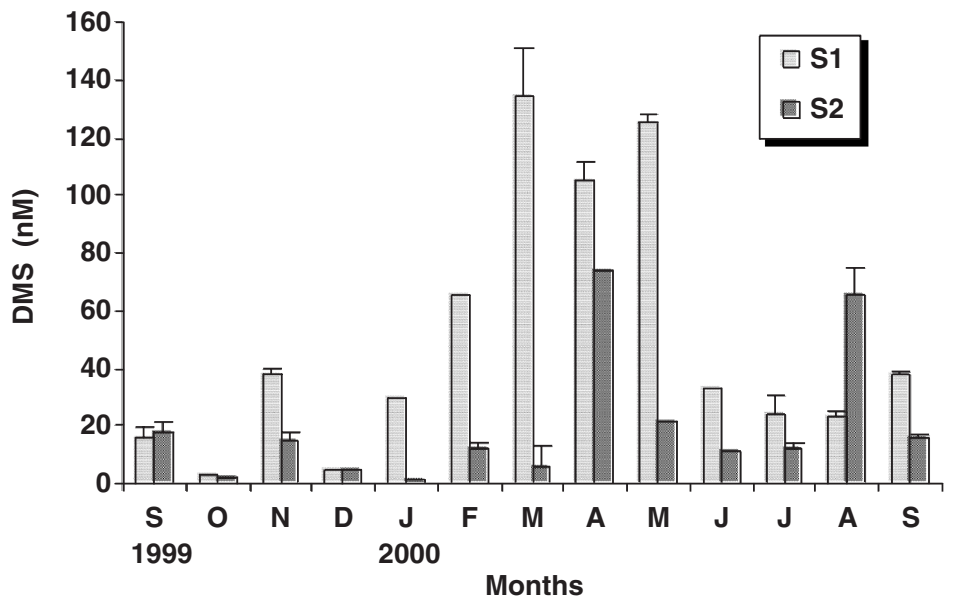

Fig. 6. Temporal variations in $\mathrm{DMSP}_{\mathrm{p}}$ (Fig. A), $\mathrm{DMSP}_{\mathrm{d}}$ (Fig. B) and DMS concentrations (Fig. C) in Little Bay $\left(\mathrm{S}_{1}\right)$ and Niel Bay $\left(\mathrm{S}_{2}\right)$. 


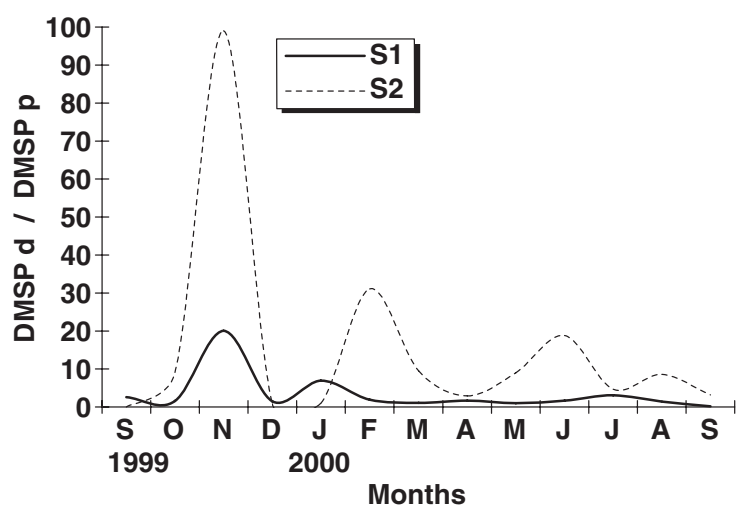

Fig. 7. Temporal variations in the $\mathrm{DMSP}_{\mathrm{d}}$ to $\mathrm{DMSP}_{\mathrm{p}}$ ratio in Little Bay $\left(\mathrm{S}_{1}\right)$ and Niel Bay $\left(\mathrm{S}_{2}\right)$.

the highest values were recorded in March ( $7 \mathrm{nM}$ for the $>90 \mu \mathrm{m}$ fraction, $40 \mathrm{nM}$ for the 5-90 $\mu \mathrm{m}$ fraction and $11 \mathrm{nM}$ for the $0.2-5 \mu \mathrm{m}$ fraction). $\mathrm{DMSP}_{\mathrm{p}}$ was mostly present in the 5-90 $\mu \mathrm{m}$ size class, especially in the spring
( $100 \%$ in May). In the $>90 \mu \mathrm{m}$ and the $0.2-5 \mu \mathrm{m}$ classes, the $\operatorname{DMSP}_{\mathrm{p}}$ levels were generally low and rarely contributed more than $20 \%$ of the total concentration, except in December (65\%) for the $0.2-5 \mu \mathrm{m}$ fraction.

In Niel Bay, the DMSP concentrations for each fraction were much lower than in Little Bay, especially for the 5-90 $\mu \mathrm{m}$ size class (Wilcoxon rank sum test: $p=0.002$ ). In this class, the temporal profile was the same as in Little Bay (Correlation Spearman test: $r=0.566 ; p=0.050)$. Again, the $5-90 \mu \mathrm{m}$ fraction contained most of the $\mathrm{DMSP}_{\mathrm{p}}$, and generally contributed to more than $50 \%$ of the total $\mathrm{DMSP}_{\mathrm{p}}$ concentration, except in summer where there were high concentration in the $>90 \mu \mathrm{m}$ fraction (39\% in August) and the $0.2-5 \mu \mathrm{m}$ fraction (50\% in July).

\subsection{Microphytoplanktonic DMSP concentration}

The 5-90 $\mu \mathrm{m}$ fraction, which is mainly composed of microphytoplankton, was identified as DMSP-rich. The

\section{(A)}

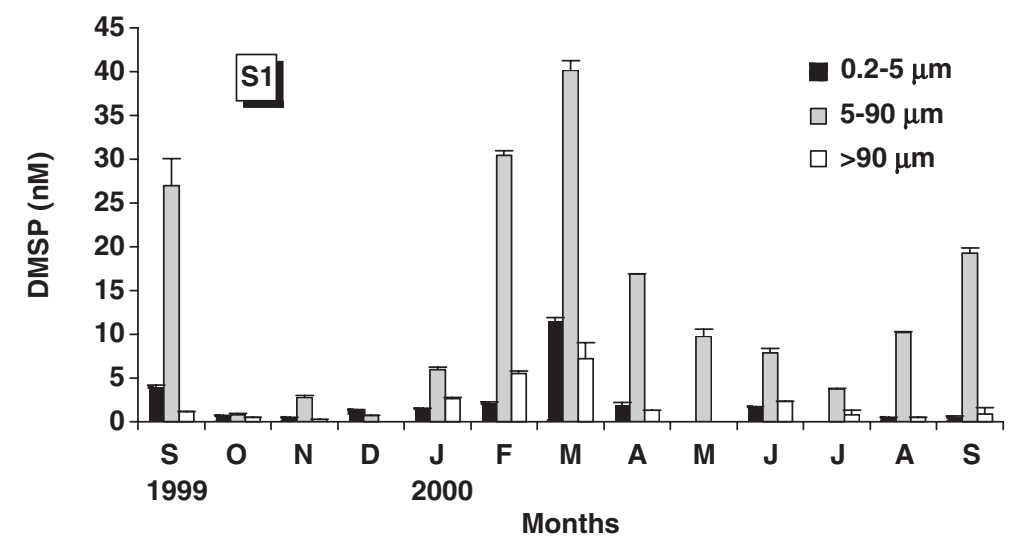

(B)

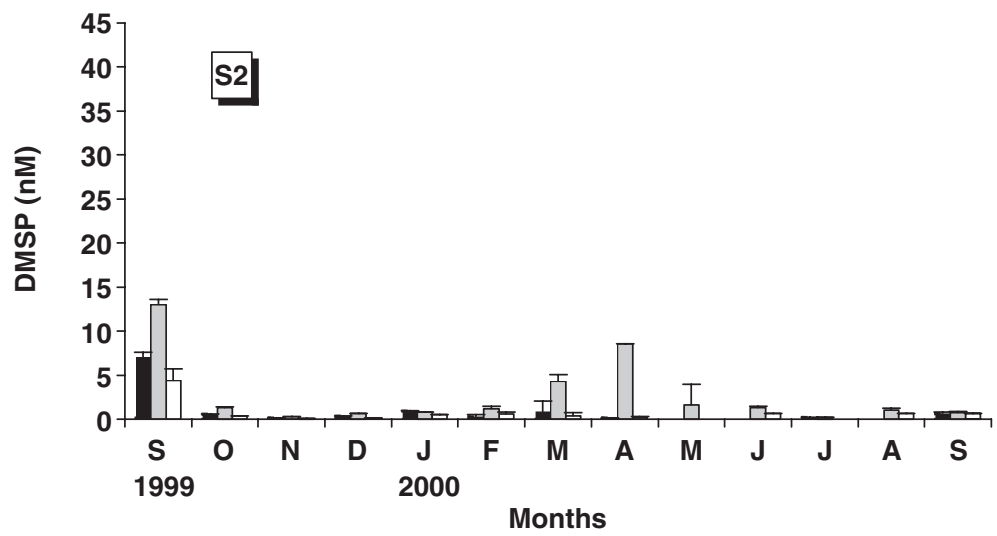

Fig. 8. Temporal variations in DMSP concentrations in $>90,5-90$ and $0.2-5 \mu \mathrm{m}$ fractions of Little Bay $\left(\mathrm{S}_{1}\right)\left(\right.$ Fig. A) and Niel Bay $\left(\mathrm{S}_{2}\right)($ Fig. B). 
(A)

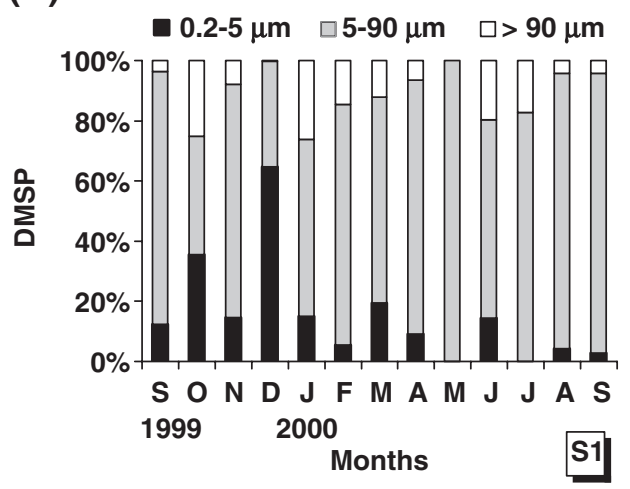

(B)

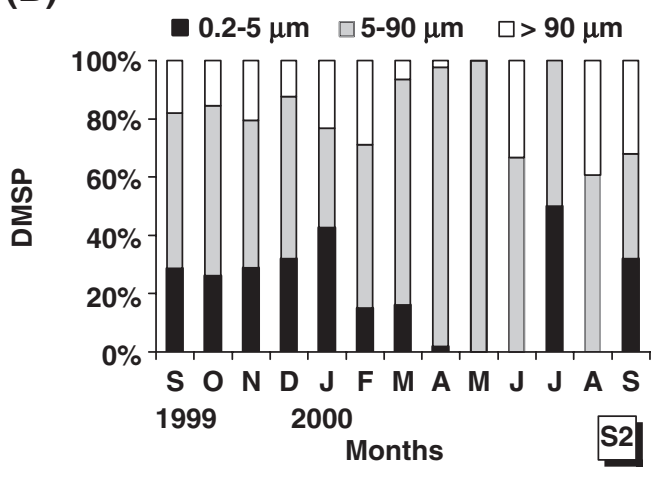

Fig. 9. Relative contributions of the $>90,5-90$ and $0.2-5 \mu \mathrm{m}$ fractions to the total $\mathrm{DMSP}_{\mathrm{p}}\left(\right.$ in \%) Little Bay $\left(\mathrm{S}_{1}\right)\left(\right.$ Fig. A) and Niel Bay $\left(\mathrm{S}_{2}\right)($ Fig. B).

microphytoplanktonic DMSP concentration was calculated as the $\mathrm{DMSP}_{\mathrm{p}}$ concentration to protein ratio for the 5-90 $\mu \mathrm{m}$ fraction. In Little Bay, these microphytoplankton concentrations ranged from $6.10^{-3} \mathrm{nmol} / \mu \mathrm{g}$ in December to $0.28 \mathrm{nmol} / \mu \mathrm{g}$ in September 2000 (Fig. 10). An increase was observed in winter, resulting in a peak in March $(0.23 \mathrm{nmol} / \mu \mathrm{g})$. In Niel Bay, this DMSP $_{\mathrm{p}}$ to protein ratio was mostly below $0.11 \mathrm{nmol} / \mu \mathrm{g}$ and was much lower than in Little Bay (Wilcoxon rank sum test: $p=0.003)$.

\subsection{Relationships with phytoplankton species}

No correlation was found between the DMSP concentrations in the 5-90 $\mu \mathrm{m}$ fraction and the phytoplankton community of Niel Bay. By contrast, in Little Bay, there was a significant correlation between this DMSP concentration and total Dinophyceae biomass

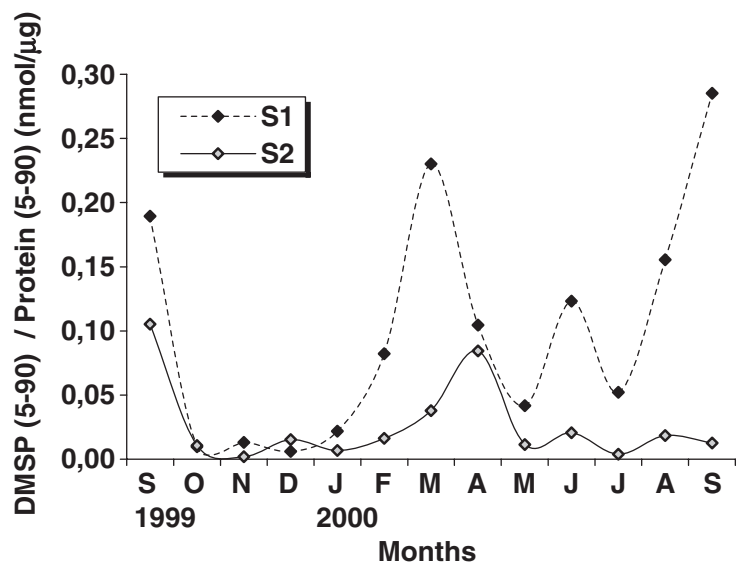

Fig. 10. Comparison of the $\mathrm{DMSP}_{\mathrm{p}}$ to protein ratio (for the 5-90 $\mu \mathrm{m}$ fraction) between Little Bay $\left(\mathrm{S}_{1}\right)$ and Niel Bay $\left(\mathrm{S}_{2}\right)$.
(Correlation Spearman test: $r=0.582 ; p=0.044)$. Among these Dinophyceae, Alexandrium minutum may be very important in the DMS(P) cycle of Toulon Bay. Indeed, its abundance was much greater between March and April, when the DMSP concentrations increased, and accounted for between 50\% (2894 cells/L) and 63\% (4914 cells/L) of the total phytoplankton abundance (Fig. 11A). This role could be confirmed by the relationship between A. minutum biomass and the DMSP concentration in the 5-90 $\mu \mathrm{m}$ fraction and by the positive correlation between this biomass and the DMS concentration (Correlation Spearman test: $r=0.709$; $p=0.014)$ (Fig. 11B).

\section{Discussion}

Over several decades, the productivity of the Mediterranean Sea has increased in response to intensified human intervention and a rise in temperature (Lacaze, 1993; Bethoux and Gentili, 1996; Duarte et al., 1999). This study aimed to describe the changes in $\operatorname{DMS}(\mathrm{P})$ concentrations due to eutrophication, to understand better the processes involved in the regulation of the sulfur species production.

Two sites close to each other were chosen in the Toulon area, where there are marked differences in the plankton abundance: the Little Bay of Toulon and Niel Bay. Previous studies have shown that Little Bay was more productive than outlying ecosystems (Jean, 2002; Jamet et al., 2005). Greater phytoplankton biomass and abundance, and increased nitrate, orthophosphate and chlorophyll $a$ concentrations, confirm that Little Bay is more eutrophic than Niel Bay. Moreover, the semienclosed configuration of Little Bay slows down the nutrient dispersion, which it contributes to increase the productivity (Barth and Fegan, 1990). However, the 
(A)

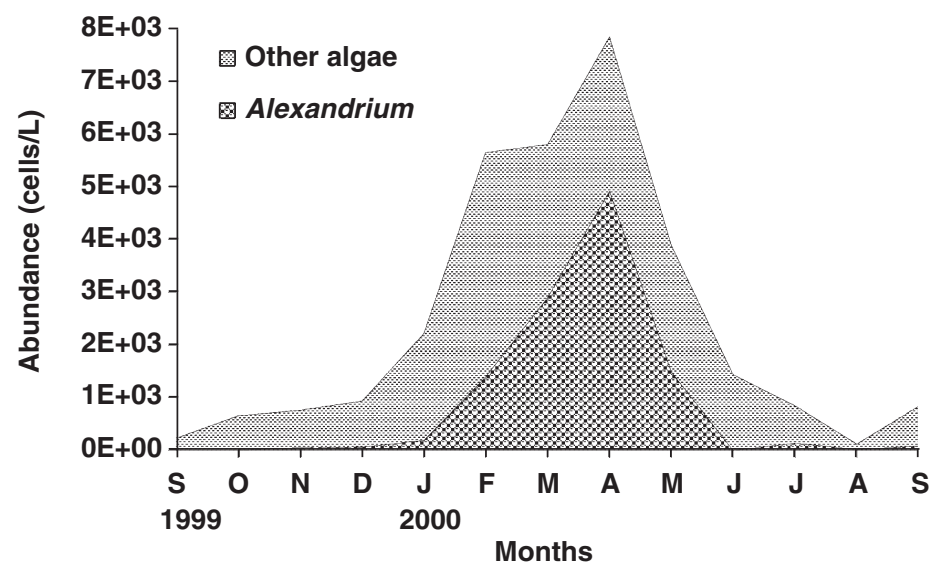

(B)

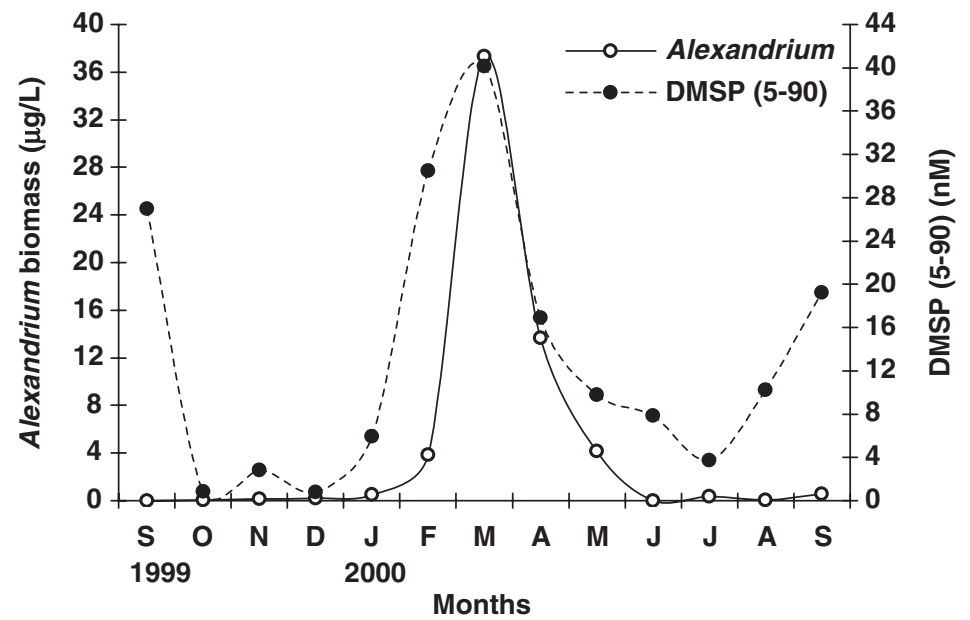

Fig. 11. Annual contribution of Alexandrium minutum to the total phytoplankton abundance (Fig. A) and relationship between DMSP concentration in the 5-90 $\mu \mathrm{m}$ fraction and A. minutum biomass (Fig. B) in Little Bay of Toulon.

absence of hypoxia or anoxia, indicates that Little Bay cannot be considered as severely eutrophicated (Guillot and Souchu in Ifremer, 2001; Jean, 2002).

In Little Bay, $\mathrm{DMSP}_{\mathrm{p}}$ concentrations were between 2 and $59 \mathrm{nM}$. In the less eutrophic Niel Bay, DMSP concentrations were significantly lower, varying between 0.5 and $24 \mathrm{nM}$. This confirms that $\mathrm{DMSP}_{\mathrm{p}}$ concentrations increase in areas where algal abundance is greater. High DMSP concentrations (between 3.4 and $4.7 \mu \mathrm{M}$ ) have also been found in Barcelona harbour (Belviso et al., 2000), and in the Gulf of Mexico where DMSP $_{p}$ concentrations are three times higher than in the oligotrophic ocean (Kiene and Linn, 2000). Hatton et al. (1999) also found higher $\mathrm{DMSP}_{\mathrm{p}}$ values in the eutrophic Coast of Oman than in the Arabian Sea. In both sites of the Toulon area, dissolved and particulate DMSP showed a strong variability with time. In Little Bay, as in Niel Bay, the highest dissolved, particulate DMSP, and DMS concentrations were recorded at the end of the winter. In colder regions of the world, the highest DMSP levels are often observed in springtime (Kwint and Kramer, 1996; Van Duyl et al., 1998). Unlike DMSP ${ }_{\mathrm{p}}$ concentrations, $\mathrm{DMSP}_{\mathrm{d}}$ concentrations were similar in the two sites, with values between 7 and $148 \mathrm{nM}$ in Little Bay and between 2 and $110 \mathrm{nM}$ in Niel Bay. These concentrations seem to be high compared to the average concentration of $14 \mathrm{nM}$ generally found in the global oceans (Kettle et al., 1999). However, Townsend and Keller (1996) also mentioned high levels in the Gulf of Maine, where DMSP ${ }_{d}$ of these temperate waters can reach up to $101 \mathrm{nM}$. In Little Bay, high DMS levels were also recorded, with an average of $49 \mathrm{nM}$ on the whole year. Similar observations were mentioned by Niki et al. (2000) in the Tokyo Bay, where elevated DMS concentrations are recorded, rising to $130 \mathrm{nM}$. DMS 
concentrations measured in the less eutrophic Niel Bay, with an annual mean value of $20 \mathrm{nM}$, are closer to levels mentioned in the literature. However, these values are still higher than concentrations encountered in the global oceans (between 0.5 and $10 \mathrm{nM}$ ) (Kettle et al., 1999), in the Gulf of La Spezia and in the Venice Lagoon (around $16 \mathrm{nM}$ ) (Boniforti et al., 1993; Moret et al., 2000). At both sites, DMS concentrations were often lower than DMSP ${ }_{d}$ concentrations. Predominance of $\mathrm{DMSP}_{\mathrm{d}}$ against DMS is mentioned by most of the authors (Turner et al., 1988). Such observations may suggest a slow enzymatic conversion by the DMSP-lyase of DMSP ${ }_{d}$ to DMS. The DMS to $\mathrm{DMSP}_{\mathrm{d}}$ ratio observed in Toulon area also indicated a slow conversion to DMS, except in March-April in Little Bay, and in August-September in Niel Bay, may be on account of a rise in temperature which could increase the enzymatic activity.

DMSP $_{p}$ usually represents the main part of the total DMSP (Turner et al., 1988; Andreae, 1990). In our study, $\mathrm{DMSP}_{\mathrm{d}}$ concentrations were always higher than $\mathrm{DMSP}_{\mathrm{p}}$ concentrations, especially in Niel Bay. Taking account of the losses by filtration, $\mathrm{DMSP}_{\mathrm{p}}$ concentrations remained lower than $\mathrm{DMSP}_{\mathrm{d}}$ concentrations. Therefore, the differences between $\mathrm{DMSP}_{\mathrm{p}}$ and $\mathrm{DMSP}_{\mathrm{d}}$ concentrations were not only due to an experimental artefact. In Niel Bay, which has a low algal biomass and low DMSP $_{p}$ concentrations, phytoplankton activity cannot fully explain the high $\mathrm{DMSP}_{\mathrm{d}}$ levels found there. It may be assumed that benthic macroalgae (possibly Posidonia oceanica present in this ecosystem), contribute to this $\mathrm{DMSP}_{\mathrm{d}}$ pool. However, oceanographic studies are carried out in pelagic waters where the contribution of benthic algae metabolism to DMSP production cannot predominate compared to phytoplankton activity. However, marine macroalgae, such as Ulva lactuca (Greene, 1962), Polysiphonia fastigiata (Challenger, 1951) or Polysiphonia lanosa (Cantoni and Anderson, 1956) contain DMSP. This suggests that macroalgae can contribute to the $\mathrm{DMSP}_{\mathrm{d}}$ pool, especially in shallow ecosystem such as Niel Bay. But, high $\mathrm{DMSP}_{\mathrm{d}}$ concentrations found in this ecosystem, may also result from a resuspension of DMSP-rich sediment. Indeed, Nedwell et al. (1994), in the North Sea, and Gambaro et al. (2002) in the Venice Lagoon, measured DMSP concentrations a thousand times higher in the sediment than in the water column. High $\mathrm{DMSP}_{\mathrm{d}}$ concentrations explain the large values in the $\mathrm{DMSP}_{\mathrm{d}}$ to $\mathrm{DMSP}_{\mathrm{p}}$ ratio. In the two ecosystems, this ratio greatly increased at the same time as a decrease in salinity after the heavy autumn rains. These hypoosmotic conditions probably affected the algal metabolism, causing cell lysis and a release of DMSP in the sea. Dickson and Kirst (1986) showed that Tetraselmis subcordiformis rapidly released intracellular DMSP after hypo-osmotic shock. Intracellular DMSP content generally increased once salinity rose again (Van Bergeijk and Stal, 2001). In our study, normal salinity recovered during October to February. At the same time, the $\mathrm{DMSP}_{\mathrm{d}}$ to $\mathrm{DMSP}_{\mathrm{p}}$ ratio decreased irregularly, suggesting a slow regulation of the algal osmotic potential, as described by Stefels (2000).

In the two study sites, the 5-90 $\mu \mathrm{m}$ fraction, which was principally composed of microphytoplankton, contained the greatest concentrations of $\mathrm{DMSP}_{\mathrm{p}}$. Belviso et al. (1993) observed at Villefranche-sur-mer that $16 \%$ of the total $\mathrm{DMSP}_{\mathrm{p}}$ was present in the 10-200 $\mu \mathrm{m}$ size fraction, against $39 \%$ of the total $\mathrm{DMSP}_{\mathrm{p}}$ observed at Banyuls. Here, the DMSP originated from heterotrophic organisms, such as microzooplankton present in the 10 $200 \mu \mathrm{m}$ fraction, rather than from phytoplankton. Meyerdierks et al. (1997) showed in the South Atlantic Ocean that most of the $\mathrm{DMSP}_{\mathrm{p}}$ was present in the 5$20 \mu \mathrm{m}$ fraction and the contribution from the $<5 \mu \mathrm{m}$ fraction was negligible, which is consistent with our results. The $\mathrm{DMSP}_{\mathrm{p}}$ concentration of this 5-90 $\mu \mathrm{m}$ fraction was always higher in the more productive Little Bay. This was also true for the DMSP to protein concentration ratio in this fraction. Therefore, the high DMSP concentrations measured in Little Bay could not only be due to a higher biomass but also to DMSP rich algae. Little Bay is characterised by a higher abundance of Dinophyceae than Niel Bay, whereas Bacillariophyceae were more abundant in this less eutrophic ecosystem (Jamet et al., 2005). The positive correlation between the total Dinophyceae biomass and the DMSP of the 5-90 $\mu \mathrm{m}$ fraction observed in Little Bay, suggests that Dinophyceae may be largely responsible for this DMSP production.

It is widely accepted that DMSP comes primarily from Dinophyceae and Prymnesiophyceae (including coccolithophorids), with Bacillariophyceae being regarded as minor producers (Keller et al., 1989; Liss et al., 1993). We recently estimated the intracellular DMSP concentration after isolation of algal cells, and showed that, in Little Bay, Dinophyceae contained more DMSP than Bacillariophyceae. These measurements also revealed that $A$. minutum may contain up to $3388 \pm$ $122 \mathrm{mM}$ of DMSP (Jean et al., 2005). In the Little Bay of Toulon, the toxic $A$. minutum species was principally responsible for the algal bloom recorded in March and April 2000 (Ifremer, 2001). In Little Bay, high DMS(P) levels were observed when A. minutum contributed to more than $50 \%$ of the total algal abundance. Therefore, this species may be a sensitive bioindicator of high DMS 
(P) content in highly eutrophic waters. In some eutrophic ecosystems of the North Sea, the non-toxic Phaeocystis microalga is also well known to be the main producer of DMS(P) (Liss et al., 1994; Stefels et al., 1995; Lancelot et al., 1987; Riegman et al., 1992).

In conclusion, our results confirm that $\operatorname{DMS}(\mathrm{P})$ concentrations are elevated in highly eutrophic waters. These high concentrations result from high phytoplankton biomass as well as the proliferation of size specific algal species such as that are high DMS(P) producers.

\section{Acknowledgments}

The authors thank the Institut Universitaire de Technologie of the Université de Toulon et du Var and the Département de Génie Biologique for technical support.

\section{References}

Andreae, M.O., 1990. Ocean-atmosphere interactions in the global biogeochemical sulfur cycle. Mar. Chem. 30, 1-29.

Barth, H., Fegan, L., 1990. Eutrophication-related phenomena in the Adriatic Sea and in other Mediterranean coastal zones. Water Pollut. Res. 16 (255 pp.).

Bates, T.S., Kiene, R.P., Wolfe, G.V., Matrai, P.A., Buck, K.R., Blomqist, B.W., Cuhel, R.L., 1994. The cycling of sulphur in surface seawater of the northeast Pacific. J. Geophys. Res. 99 (C4), 7835-7843.

Belin, C., Beliaeff, B., Raffin, B., Rabia, M., Ibanez, F., 1995. Phytoplankton time-series data of the French phytoplankton monitoring network: toxic and dominant species. In: Lassus, P., Arzul, G., Erard, E., Gentien, P., Marcaillou, C. (Eds.), Harmful Marine Algal Blooms. Technique et Documentation Lavoisier, Intercept.

Belviso, S., Buat-Menard, P., Putaud, J.P., Nguyen, B.C., Claustre, H., Neveux, J., 1993. Size distribution of dimethylsulfoniopropionate (DMSP) in areas of the tropical northeastern Atlantic Ocean and the Mediterranean Sea. Mar. Chem. 44, 55-71.

Belviso, S., Christaki, U., Vidussi, F., Marty, J.C., Vila, M., Delgado, M., 2000. Diel variations of the DMSP-to-chlorophyll a ratio in Northwestern Mediterranean surface waters. J. Mar. Syst. 25, 119-128.

Bethoux, J.P., Gentili, B., 1996. The Mediterranean Sea, coastal and deep-sea signatures of climatic and environmental changes. J. Mar. Syst. 7, 383-394.

Boniforti, R., Emaldi, P., Ferraroli, R., Maspero, M., Nair, R., Novo, A., 1993. Preliminary data on DMS concentration in seawater samples collected from La Spezia Gulf (Ligurian Sea). In: Restelli, G., Angeletti, G. (Eds.), Dimethylsulfide: Oceans, Atmosphere and Climate. ECSC, EEC, EAEC, Kluwer, Brussels and Luxembourg: $163-172$.

Cantoni, G.L., Anderson, D.G., 1956. Enzymatic cleavage of dimethylpropiothetin by Polysiphonia lanosa. J. Biol. Chem. 222, 171-177.

Challenger, F., 1951. Biological methylation. Adv. Enzymol. 12, 429-491.

Charlson, R.J., Lovelock, J.E., Andreae, M.O., Warren, S.G., 1987. Oceanic phytoplankton, atmospheric sulfur, cloud albedo and climate. Nature 326, 655-661.
Dacey, J.W.H., Blough, N.V., 1987. Hydroxide decomposition of DMSP to form DMS. Geophys. Res. Lett. 14 (12), 1246-1249.

Despiau, S., Gourdeau, J., Jamet, D., Geneys, C., Jamet, J.L.J., 2002. Seawater DMS in a perturbed coastal ecosystem. Hydrobiologia 489, 107-115.

Dickson, D.M.J., Kirst, G.O., 1986. The role of $\beta$-dimethylsulfoniopropionate, glycine betaine and homarine in the osmoacclimation of Platymonas subcordiformis. Planta 167, 536-543.

Duarte, C.M., Agusti, S., Kennedy, H., Vaque, D., 1999. The Mediterranean climate as a template for Mediterranean marine ecosystems: the example of the northeast Spanish littoral. Prog. Oceanogr. 44, 245-270.

Gambaro, A., Moret, I., Piazza, R., Da Rin, E., Turetta, C., Cescon, P., 2002. Winter evolution of DMS and DMSP in Venice lagoon water and sediment. Ann. Chim. 217-227.

Greene, R.C., 1962. Biosynthesis of dimethyl- $\beta$-propiothetin. J. Biol. Chem. 237, 2251-2254.

Hatton, A.D., Malin, G., Liss, P.S., 1999. Distribution of biogenic sulfur compounds during and just after the southwest monsoon in the Arabian Sea. Deep-Sea Res. II 46 (3-4), 617-632.

Ifremer, 1997. La surveillance de la qualité des eaux côtières à l'Ifremer. Ifremer Internal Report. DEL/97-10/, Issy les Moulineaux, p. 21.

Ifremer, 2001. In: Ifremer (Ed.), L'eutrophisation des eaux marines et saumâtres en Europe, en particulier en France. 59 pp.

Jamet, J.L., Jean, N., Boge, G., Richard, S., Jamet, D., 2005. Plankton succession and assemblage structure in two neighbouring littoral ecosystems in the north-west Mediterranean Sea. Mar. Freshw. Res. 56: 69-83.

Jean, N., 2002. Etude du DMSP et du DMS dans deux écosystèmes littoraux marins de niveaux trophiques différents (Méditerranée Occidentale, France): relations avec les facteurs abiotiques et biotiques. Ph.D. Thesis, Univ. Toulon et du Var, France, pp. 283.

Jean, N., Boge, G., Jamet, J.L., Richard, S., Jamet, D., 2005. Annual contribution of different plankton size classes to particulate dimehylsulfoniopropionate in a marine perturbed ecosystem. J. Mar. Syst. 53 (1-4), 235-247.

Keller, M.D., Bellows, W.K., Guillard, R.R.L., 1989. Dimethylsulfide production in marine phytoplankton. In: Saltzman, E.S., Cooper, W.J. (Eds.), Biogenic Sulfur in the Environment. American Chemical Society, Washington D.C., pp. 167-182.

Kettle, A.J., et al., 1999. A global database of sea surface dimethylsulfide (DMS) measurements and a procedure to predict sea surface DMS as a function of latitude, longitude, and month. Glob. Biogeochem. Cycles 13, 399-444.

Kiene, R.P., Linn, L.J., 2000. Distribution and turnover of dissolved DMSP and its relationship with bacterial production and DMS in the Gulf of Mexico. Limnol. Oceanogr. 45, 849-861.

Kiene, R.P., Service, S.K., 1991. Decomposition of dissolved DMSP and DMS in estuarine waters: dependence on temperature and substrate concentration. Mar. Ecol., Progr. Ser. 76, 1-11.

Kiene, R.P., Linn, L.J., Gonzalez, J., Moran, M.A., Bruton, J.A., 1999. Dimethylsulfoniopropionate and methanethiol are important precursors of methionine and protein-sulfur in marine bacterioplankton. Appl. Environ. Microbiol. 65, 4549-4558.

Kirst, G.O., Thiel, C., Wolff, H., Nothnagel, J., Wanzek, M., Ulmke, R., 1991. Dimethylsulfoniopropionate (DMSP) in icealgae and its possible biological role. Mar. Chem. 35, 381-388.

Kwint, R.L.J., Kramer, K.J.M., 1996. Annual cycle of the production and fate of DMS and DMSP in a marine coastal system. Mar. Ecol., Prog. Ser. 134, 217-224.

Kwint, R.L.J., Kramer, K.J.M., Baart, A.C., Verhagen, H.L.M., 1993. The production of DMS by a plankton community: a mesocosm 
experiment. In: Restelli, G., Angeletti, G. (Eds.), Dimethylsulfide: Oceans, Atmosphere and Climate. Kluwer Academic Publishing Dordrecht, The Netherlands, pp. 53-62.

Lacaze, J.C., 1993. In: Masson (Ed.), La dégradation de l'environnement côtier: Conséquences écologiques.

Lancelot, C., Billen, G., Sournia, A., Weisse, T., Coljin, F., Veldhuis, M.J.W., Davies, A., Wassmann, P., 1987. Phaeocystis blooms and nutrient enrichment in the continental coastal zones of the North Sea. Ambio 16, 38-46.

Le Poupon, C., 1994. Automatisation d'un procédé d'analyse de l'azote organique dissous après minéralisation en conditions réductrices. Ph.D. Thesis, Univ. Toulon et du Var, France, pp. 182.

Liss, P.S., Malin, G., Turner, S.M., 1993. Production of DMS by marine phytoplankton. In: Restelli, G., Angeletti, G. (Eds.), Dimethylsulfide: Oceans, Atmosphere and Climate. Kluwer Academic Publishing Dordrecht, The Netherlands, pp. 1-14.

Liss, P.S., Malin, G., Turner, S.M., Holligan, P.M., 1994. Dimethylsulfide and Phaeocystis: a review. J. Mar. Syst. 5, 41-53.

Lohman, H., 1908. Untersuchungen zur Feststellung des vollstandigen Gehaltes des Meeres an Plankton. Wiss. Meeresunters., Abt. Kiel N. F. 10, 132-170.

Lorenzen, C.J., 1967. Determination of chlorophyll and pheopigments: spectrophotometric equations. Limnol. Oceanogr. 12, 343-346.

Lowry, O.H., Rosebrough, N.J., Farr, A.L., Randall, R.J., 1951. Protein measurement with the Folin phenol reagent. J. Biol. Chem. 193, 265-275.

Lund, J.W., Kipling, C., Le Cren, E.D., 1958. An inverted microscope method of estimating algal numbers and the statistical basis of estimations by counting. Hydrobiologia 11, 143-170.

Meyerdierks, D., Bolt, B., Kirst, G.O., 1997. Spatial and vertical distribution of particulate dimethylsulfoniopropionate (DMSP) during spring in the Atlantic sector of the Southern Ocean. DeepSea Res. 44, 283-297.

Moret, I., Gambaro, A., Piazza, R., Barbante, C., Andreoli, C., Corami, F., Scarponi, G., 2000. The seasonal variations of dimethylsulphide and carbon disulphide in surface waters of the Venice lagoon. Mar. Chem. 71, 283-295.

Murphy, J., Riley, J.P., 1962. A modified single solution method for the determination of phosphate in natural waters. Ann. Chem. Acta $27,31-36$

Nedwell, D.B., Shabbeer, M.T., Harrison, R.M., 1994. Dimethylsulfide in North Sea waters and sediments. Estuar. Coast. Shelf Sci. 39, 209-217.

Niki, T., Kunugi, M., Otsuki, A., 2000. DMSP-lyase activity in five marine phytoplankton species: its potential importance in DMS production. Mar. Biol. 136 (5), 759-764.

Paillard, M., et al., 1993. Cartographie de l'herbier de Posidonie et des fonds marins environnants de Toulon à Hyères (Var-France). Reconnaissance par sonar latéral et photographie aérienne. Notice de présentation. Ifremer and Gis Posidonie Publ, Fr., pp. 1-36. +3 cartes annexes.
Riegman, R., Noordeloos, A.A.M., Cadée, G.C., 1992. Phaeocystis blooms and eutrophication of the continental zones of the North Sea. Mar. Biol. 112, 479-484.

Simo, R., 1998. Trace chromatographic analysis of dimethylsulfoxide and related methylated sulfur compounds in natural waters. J. Chromatogr., A 807, 151-164.

Simo, R., Grimalt, J.O., Albaiges, J., 1993. Field sampling and analysis of volatile reduced sulphur compounds in air, water and wet sediments by cryogenic trapping and gas chromatography. J. Chromatogr., A 655, 301-307.

Stefels, J., 1997. The Smell of the Sea: Production of Dimethylsulphoniopropionate and its Conversion into Dimethylsulphide by the Marine Phytoplankton Genus Phaeocystis sp. 147 pp.

Stefels, J., 2000. Physiological aspects of the production and conversion of DMSP in marine algae and higher plants. J. Sea Res. 43, 183-197.

Stefels, J., Van Boekel, W.H.M., 1993. Production of DMS from dissolved DMSP in axenic cultures of the marine phytoplankton species Phaeocystis sp. Mar. Ecol., Prog. Ser. 97, 11-18.

Stefels, J., Dijkhuizen, L., Gieskes, W.W.C., 1995. DMSP-lyase activity in a spring phytoplankton bloom off the Dutch coast, related to Phaeocystis abundance. Mar. Ecol., Prog. Ser. 123, 235-243.

Steinke, M., Malin, G., Gibb, S.W., Burkill, P.H., 2002. Vertical and temporal variability of DMSP-lyase activity in a coccolithophorid bloom in the northern North Sea. Deep Sea Res. II 49, 3001-3016.

Sunda, W., Kieber, D.J., Kiene, R.P., Huntzman, S., 2002. An antioxidant function for DMSP in marine algae. Nature 418 (6895), 317-320.

Townsend, D.W., Keller, M.D., 1996. Dimethylsulfide and dimethylsulfoniopropionate in relation to phytoplankton in the Gulf of Maine. Mar. Ecol., Prog. Ser. 137, 229-241.

Turner, S.M., Malin, G., Liss, P.S., Harbour, D.S., Holligan, P.M., 1988. The seasonal variation of DMS and DMSP concentrations in nearshore waters. Limnol. Oceanogr. 33 (3), 364-375.

Utermohl, H., 1958. Zur Vervollkommung der quantitativen Phytoplankton-Methodik. Mitt. Int. Ver. Theor. Angew. Limnol. 9, 1-38.

Van Bergeijk, S.A., Stal, L.J., 2001. Dimethylsulfoniopropionate and dimethylsulfide in the marine flatworm Convoluta roscoffensis and its algal symbiont. Mar. Biol. 138, 209-216.

Van Duyl, F., Gieskes, W.W.C., Kop, A.J., Lewis, W.E., 1998. Biological control of short-term variations in the concentration of DMSP and DMS during a Phaeocystis spring bloom. J. Sea Res. 40, 221-231.

Van Rijssel, M., Buma, A.N.G., 2002. UVR induced stress does not affect DMSP synthesis in the marine prymnesiophyte Emiliana huxleyi. Aquat. Microb. Ecol. 28, 167-174.

White, R.H., 1982. Analysis of dimethylsulfonium compounds in marine algae. J. Mar. Res. 40 (2), 529-536.

Wood, E.D., Armstrong, A.A.J., Richards, F.A., 1967. Determination of nitrate in sea water by cadmium-copper reduction to nitrite. J. Mar. Biol. Assoc. U.K. 47, 23-31. 